\title{
Rahvatantsu harrastamine ja suurpidudest osavõtmine: põhjused ja seosed subjektiivse heaoluga ${ }^{1}$
}

\author{
Stanislav Nemeržitski, Iivi Zajedova
}

Teesid: Harrastustegevus, millest on välja kasvanud suurpidude korraldamine, ulatub Eestis 19. sajandisse. Aja jooksul on mõnest harrastusest saanud nii vaba aja veetmise viis kui ka kultuurisündmuse sisu. Teatavasti suurendavad vaba aja tegevused oluliselt subjektiivset heaolutunnet, neil on positiivne emotsionaalne, sotsiaalne ja psühholoogiline toime. Käesoleva artikli aluseks oleva uurimuse keskmes oli rahvatantsuga tegelemise põhjuste väljaselgitamine ja uurimine, milline on selle seos heaoluga täiskasvanute seas. Uurimus viidi läbi Eestis ja välismaal elavate eestlaste hulgas, kombineerides kvantitatiivseid ja kvalitatiivseid meetodeid. Tulemustest selgub, et kõige tähtsamat rolli rahvatantsijate motiveerimisel nii rahvatantsu treeningutel kui ka üritustel mängivad sotsiaalsed faktorid, kuigi rahvatantsuga on seotud ka õppimine ja teised heaolutunde aspektid.

Märksõnad: harrastustegevus, rahvatants, subjektiivne heaolu, vaba aja tegevus

\section{Teoreetiline taust}

\section{Subjektiivne heaolu ja seda mõjutavad faktorid}

Subjektiivset heaolu (edaspidi $\mathrm{SH}$ ) on kirjeldatud kui viimase kümnendi üht kõige huvipakkuvamat uurimisvaldkonda psühholoogias (Tamannaeifar \& Motaghedifard 2014). Positiivse psühholoogia esilekerkmist peetakse peamiseks põhjuseks, miks on hüppeliselt suurenenud huvi inimese subjektiivse heaolutunde vastu. SH kontseptsiooni juured ulatuvad 1980. aastatesse. Teooria ühe rajaja Ed Dieneri (1984) järgi on SH komponentideks eluga rahulolu, tugevad positiivsed tunded ja nõrgalt esinevad negatiivsed tunded. Teooriat arendasid edasi Ed Diener, Eunkook M. Suh, Richard Lucas ja Heidi L. Smith (1999), ning see viis $\mathrm{SH}$ olemuse mitmekülgse kirjeldamiseni. Selle mudeli järgi on SH-l neli põhilist joont: üldine eluga rahulolu, mis on inimese elu kognitiivne hinnang; meeldiv/positiivne mõju, mis on igasuguste positiivsete emotsioonide 
korduv olemasolu; ebameeldiv/negatiivne mõju, mis on igasuguste negatiivsete emotsioonide hiljutine olemasolu; ja lõpuks konkreetse valdkonnaga rahulolu tase (Diener et al. 1999). Ed Diener ja Martin E. P. Seligman (2004) kirjeldavad SHd kui üht põhielementi eluga rahulolu individuaalsel ja ühiskondlikul tasandil. Sarnaselt õnnetundele, mis aja jooksul muutub, võivad ka inimese SH tasemed oluliselt varieeruda vastavalt kontekstile ja hindamismetoodikale (Bostic \& Ptacek 2001; Carter 2004). Käesolevas artiklis püüame kontseptualiseerida võimalikke seoseid $\mathrm{SH}$ ja rahvatantsuharrastuse vahel, eeskätt otsime seoseid rahvatantsuga tegelemise põhjustes.

Corey L. M. Keyes ja Jeana L. Magyar-Moe (2003) on pakkunud välja SH alternatiivse mudeli, millel on kolm alamskaalat: emotsionaalne, psühholoogiline ja sotsiaalne heaolu. Psühholoogilise heaolu puhul on Carol D. Ryff (1989) rõhutanud $\mathrm{SH}$ oluliste komponentidena keskkonna valdamise meisterlikkust ja positiivseid suhteid teiste inimestega. Keyes defineerib sotsiaalset heaolu kui "inimese hinnangut oma positsioonile ja funktsioneerimisele ühiskonnas" (Keyes 1998: 122). Selle definitsiooni järgi moodustavad sotsiaalse heaolu järgmised viis faktorit: sotsiaalne integreerumine, sotsiaalne tunnustus, sotsiaalne panus, sotsiaalne aktualiseerumine ja sotsiaalne sidusus (ibid.). Sotsiaalsed tegevused (eriti vaba aja tegevused) aitavad luua sotsiaalseid suhteid, toetavad positiivseid emotsioone ja parandavad seega inimese üldist elukvaliteeti (Brajša-Žganec \& Merka \& Šverko 2011). Rahvatantsu harrastamine on antud kontekstis võimas vahend, suurendamaks inimese sotsiaalset heaolu mitmel viisil. Esiteks annab see võimaluse kohtuda inimestega, kellel on samad huvid ning jagada kaaslastega huvi rahvakunsti vastu. Teiseks võimaldab see panustada kogukonna heaolusse: osalemine omakultuuri suurpidudel võib innustada nii üksikisikut kui ka kogukonda/ühiskonda tervikuna. Kolmandaks võib rahvatantsuharrastust vaadelda sotsiaalse aktualiseerimise vahendina rahvusliku kultuuripärandi säilitamise kontekstis osalemise kaudu.

Vaba aja tegevused kajastuvad Ed Dieneri mudelis (1999) kui rahulolu oma tegevusvaldkonnaga. Veelgi enam: sageli pakuvad nad võimalust loominguliseks eneseväljenduseks kas siis käelise tegevuse, grupitegevuse (tantsimine, sport, laulmine) kaudu või isegi eneseteostust. Seetõttu on vaba aja tegevuse kui isiku SH mõjuri uurimine sama tähtis kui muude $\mathrm{SH}$ aspektide uurimine. Mitmed varasemad uurimused on näidanud vaba aja tegevuse ja $\mathrm{SH}$ vahelist positiivset seost, näiteks perekonna ja sõprade külastamine, spordimängude harrastamine, televiisori vaatamine või raadio kuulamine (Menec \& Chipperfield 1997; Yarnal \& Chick \& Kerstetter 2008) või kunstiga tegelemine (Reynolds \& Lim 2007). Galina Balatsky ja Ed Dieneri klassikaline uurimus (1993) näitab, et tolleaegse Nõukogude Liidu üliõpilaste silmis oli suurimaks SH alli- 
kaks rahulolu vaba aja ja puhkusega. Michael Minkovi (2009) läbilõikeuurimus mitmekümne riigi elanike seas näitas selgelt, et vaba aja harrastused on üks tugevamaid ennustatavaid faktoreid indiviidi õnnelikkuse korral.

David Newmani, Louis Tay ja Ed Dieneri uurimuses (2014) pakutakse välja kontseptuaalne mudel, mis näitab vaba aja ja SH vahelisi seoseid. Selle mudeli kohaselt mõjutab vaba aja tegevus globaalset SHd viie põhilise psühholoogilise mehhanismi abil: (a) eemaldumine-taastumine tööga põhjustatud stressist, jõuvarude säilitamine ja taastamine; (b) autonoomia kui kõikehaarava heaolu üks põhilisi tingimusi; (c) meisterlikkus, mis tekitab vajalikke väljakutseid ning õppimisvõimalusi; (d) tähenduslikud vaba aja tegevused, mis võimaldavad inimesel saavutada elus midagi tähtsat või väärtuslikku; ning (e) kuhugi kuulumine kui vahend, millega võib luua kestvaid sotsiaalseid suhteid ning tugevdada ühtekuuluvust (Newman et al. 2014). Inimese SH hindamisel mängib olulist rolli veel üks vaba aja veetmise aspekt - saavutus. Tegelemine millegi meeldivaga pakub võimalust saavutada reaalseid edusamme - see aga omakorda tõstab enesekindlust ning suurendab SHd (Brown \& MacDonald \& Mitchel 2015; Uchida, Norasakkunkit \& Kitayama 2004; Diener \& Diener 1995).

Eelnevat arvestades on oluline kaardistada inimesi rahvakunstiga tegelema suunavaid motivatsioonitegureid. Millised on rahvakunstiga ja konkreetselt rahvatantsuharrastusega tegelemise kõige sagedasemad põhjused? Mil määral mõjutavad välised ja sisemised motivaatorid harrastusi? Lisaks sellele on oluline mõista, millist tähendust omistatakse rahvatantsule kui tegevusele.

\section{Rahvatants kui rahvakunstiga tegelemine}

Artikli aluseks olev uurimistöö keskendus rahvatantsule kui ühele harrastusele. Harrastustegevus kui selline ja selle ohtrad alaliigid on märksa laiem, komplekssem ja üldisem uurimisvaldkond. Antud uurimuse raames keskendusime pigem rahvatantsu vaba aja veetmise aspektile, mitte kultuurinähtusele või -pärandile. Rahvatants on olnud eestlastele tähtis rahvakultuuri traditsioonide säilitamise seisukohalt, kuid samaaegselt on ta ka sotsialiseerumisvahend, kaaslastega suhtlemise vahend, liites ka erineva taustaga inimesi (Rüütel \& Kapper 2015: 29). Vaatamata sellele, et rahvatantsu traditsioonid ulatuvad sajandite taha, peetakse Eestis rahvatantsuliikumise esimeseks suureks tähiseks 1926. aasta eesti omakultuuri õhtut, mille toimet harrastusrahvatantsule, selle arengule, saab võrrelda esimese laulupeo mõjuga eesti koorikultuurile (Aassalu 1999: 3-4).

Kõige tähtsamaks esimeste üldtantsupidude seas võib pidada I Eesti mänge 1934. aastal ning II Eesti mänge 1939. aastal (Adari \& Mikkin 1939). Need peod 
andsid tugeva tõuke rahvatantsu arengule nii Eesti esimesel iseseisvusperioodil kui ka hiljem nõukogude okupatsiooni ajal. Eesti suurte üldtantsupidude sündi võib vaadelda kaheti. Ühelt poolt võiks seda kirjeldada kui midagi eestlastele igiomast, teisalt on see suhteliselt uus nähtus (tekkis alles 20. sajandi esimestel kümnenditel) (Zajedova 2008a). Siiski on selle traditsiooni väärtus ja tähendus nii oluline, et 2003. aastal kanti Baltimaade laulu- ja tantsupidude traditsioon UNESCO inimkonna suulise ja vaimse kultuuripärandi meistriteoste nimekirja.

Uurides rahvatantsuharrastuse ja rahvatantsu suurürituste rolli Eestis, tuleb märkida, et pärast Teist maailmasõda toimus rahvakultuuris (nagu muudeski valdkondades) jagunemine. Paljud Eesti Vabariigi kodanikud põgenesid Nõukogude okupatsiooni eest Saksamaale ja Rootsi, kust hiljem liiguti edasi teistesse lääneriikidesse USAsse, Kanadasse ja Austraaliasse (Kumer-Haukanõmm \& Rosenberg \& Tammaru 2006). Lisaks olid eestlased küüditamise tulemusena sattunud elama Venemaa eri paikadesse, mistõttu nende rahvuslikkultuuriline identiteet sattus ohtu (eestlaste identiteedist Venemaal vt lähemalt nt Korb 2015, 2014, 2012). Seega jagunes eesti rahvas laias laastus kolmeks eraldi asuvaks rahvusrühmaks: lääneriikidesse põgenenud väliseestlased, kodueestlased ja need, kes küüditamise tulemusena olid sunnitud asuma elama väljaspool kodumaad. Niisugune jaotus kestis kuni raudse eesriide langemiseni 1991. aastal (Arraste \& Zajedova \& Rüütel 2011).

Artiklis keskendutakse kodueestlastele ja läänemaailma põgenenud eestlastele. Enamik sotsiaalse interaktsiooni nähtustest (keel, suhted, päevauudised, jne) oli neis eestlaste kogukondades täiesti erinev. See, mis mõlemat sidus, oli traditsiooniline harrastustegevus (laulud, tantsud ja rahvarõivad), aidates pärast Teist maailmasõda nii Eestis kui ka väljaspool Eestit säilitada oma rahvuslikke juuri (Zajedova 2008a; Rüütel \& Zajedova \& Arraste 2013). Mõlemas lahutatud kogukonnas püüti säilitada oma traditsioone, kuigi tingimused ja mõjutused olid erinevad, mille tõttu eesti rahvatantsu areng sõltus elukohariigist (Zajedova \& Rüütel 2014).

Rahvatants on viimastel aastatel seotud selliste uuenduslike algatustega nagu meeste tantsupidu (esmakordselt 2006. aastal), naiste tantsupidu (2007. aastal), "Kaera-Jaan Euroopasse", teatetants (http://www.errs.ee/). Esmakordselt peeti 2011. aastal rahvusvahelist tantsupäeva ja ning rahvatants kuulutati Eestis aasta teemaks. 2014. aastal kuulutas Eesti Vabariigi Kultuuriministeerium tuntud rahvatantsuõpetaja Ilme Adamsoni aasta kodanikuks. Ka väljaspool Eestit asuvates eestlaste kogukondades nt USAs, Austraalias, Kanadas, Rootsis ja Inglismaal korraldatakse tänaseni regulaarseid suurpidusid, kus rahvatantsul on oma traditsiooniline ja tähtis roll (vt Zajedova 2015, 2013, 2008b). 
Vaatamata 20. sajandil Eestis ja mujal toimunud suurtele muutustele säilitas rahvatants eestlaste silmis olulise tähenduse.

\section{Uurimus}

\section{Eesmärk ja uurimisküsimused}

Võttes arvesse varasemaid teoreetilisi käsitlusi ja eesti rahvatantsu ajaloolist traditsiooni, pöörab käesolev uurimus põhiliselt tähelepanu sellele, mis motiveerib rahvatantsuga tegelema ja suurpidudel osalema. Selleks koguti andmeid rahvatantsuharrastajate motiveerituse kohta nii kodu- kui ka väliseesti kogukondades. Lähtudes teoreetilisest taustast ja uurimisfookusest keskenduti järgmistele küsimustele:

- Millised on põhilised rahvatantsuga tegelemise põhjused?

- Millised on peamised rahvatantsuüritustel osalemise põhjused?

- Mis tähendus on rahvatantsuga tegelemisel eri keskkondades ning kuidas seda tähendust edasi antakse (Eestis ja välismaal)?

- Milline on rahvatantsu traditsiooni tähtsus kodu- ja väliseestlaste silmis?

Püstitatud küsimustele vastuste saamiseks viidi läbi uurimus, kasutades andmete kogumiseks kvalitatiivseid ja kvantitatiivseid meetodeid. Seejuures pöörati tähelepanu teema erinevatele aspektidele. Autoritele teadaolevalt on see esimene katse kasutada eesti rahvatantsu uurimisel kombineeritud uurimismeetodit. Käesolev uurimus püüab täiendada olemasolevaid andmeid, näidates, kuidas väikekultuurid ja -rahvad võivad püsima jääda ning oma kultuuripärandit järgmistele põlvkondadele edasi anda. Üha enam globaliseeruvas maailmas, kus aina rohkem on ülekaalus universaalsed, suuremad ja domineerivad kultuurid ning üha olulisemaks muutub väikekultuuride (sh ka Eesti kultuur) unikaalsuse säilitamine ja nende sidumine noorema põlvkonna kaasaegse elu igapäevaste tegevustega. Lisaks püüab artikkel leida seoseid rahvatantsuga tegelemise põhjuste ja heaolutunde emotsionaalsete aspektide vahel.

\section{Meetod}

Küsimustele vastamisel püütakse kombineerida nii kvantitatiivset kui ka kvalitatiivset meetodit. Kvantitatiivne, kirjaliku testina läbiviidud uurimus keskendus rahvatantsuharrastuse ja rahvatantsupidudel osalemise motiivi- 
dele. Kvalitatiivse uurimuse raames viidi nii kodu- kui ka väliseesti (enamik uuritavatest olid eesti juurtega) rahvatantsijatega läbi poolstruktureeritud intervjuud, kus põhifookus oli suunatud rahvatantsuharrastusele, selle olulisusele rahvuskultuuri säilitamisel ning rahvatantsu suurpidudel osalemise põhjustele. Uurimuse kvalitatiivse etapi eesmärk oli täiendada kvantitatiivses etapis saadud tulemusi, illustreerimaks ning avamaks nende sisu ja tähendust rahvatantsuharrastajate silmis.

\section{Kvantitatiivne uurimus}

Antud etapi valimi koguarvust $(\mathrm{n}=285)$ oli $36 \%(\mathrm{n}=102)$ mehi ja $63 \%$ $(\mathrm{n}=178)$ naisi, 5 respondenti jätsid soo märkimata. Kodueestlastest respondentide seas oli mehi $33 \%(n=60)$ ja naisi $67 \%(n=120)$. Väliseesti respondentidest moodustasid mehed $43 \%(\mathrm{n}=43)$ ja naised $57 \%(\mathrm{n}=57)$.

Vastanute keskmine vanus oli 33,75 aastat (standardhälve/SD = 13.55); enam kui $70 \%$ kõikidest vastanutest $(n=196)$ olid nooremad kui 40 aastat. Haridustasemelt oli enamal kui 60\% ( $\mathrm{n}=172)$ kõrgharidus. Geograafilise asukoha poolest oli 64\% ( $\mathrm{n}=180)$ vastanutest pärit Eestist, 18\% ( $\mathrm{n}=50)$ Austraaliast, 9\% $(\mathrm{n}=26)$ USAst, ja 6\% $(\mathrm{n}=18)$ Kanadast. Venemaalt, Rootsist ja Ühendkuningriigist vastas igast riigist kaks esindajat.

Respondendid valiti vastavalt nende võimalusele ning soovile osaleda uuringus. Sageli mõjutas küsitletute osalemissoovi (nii positiivselt kui ka negatiivselt) rahvatantsurühma juht/õpetaja. Kokku jagati empiirilise uurimisosa jaoks välja 520 ankeeti, täidetuna tagasi saadud 285 ankeeti moodustavad seega $55 \%$ kõigist jagatud ankeetidest.

Uurimuse mõõtmisvahendiks oli küsitlusankeet. See koosnes järgmistest teemadest:

- rahvatantsu tähtsus vastajale;

- rahvatantsuüritustel osalemise tähtsus;

- erinevatel rahvatantsuüritustel käimise motivatsioon;

- hinnang rahvatantsu tähtsusele kultuuriruumis tervikuna;

- üldandmed: sugu, vanus, haridus, eriala, rahvatantsu harrastamise kogemus aastates.

Ankeedid jagati rahvatantsijatele nii Eestis kui ka väljaspool Eestit tantsutrennide ajal, otse suurpidudel või paludes rahvatantsujuhte lasta täita ankeet muul ajal. Selleks, et säilitada respondentide anonüümsust, esitatakse tulemused üldistatud kujul, jättes välja kogu isikliku teabe. 
Andmeid analüüsiti, kasutades statistikaprogrammi SPSS 22.0 for Windows, rakendades regressioonianalüüsi, korrelatsiooni ja t-testi.

Kvantitatiivse uurimuse tulemustena selgusid peamised põhjused, miks täiskasvanud kodu- ja väliseestlased tegelevad rahvatantsuga. Nendeks on: (a) positiivsete emotsioonide väljendamine, (b) kaaslaste ja rühmaliikmetega suhtlemine, (c) hea füüsilise vormi säilitamine, (d) oma rahva/riigi esindamine, (e) publikule esinemine ja (f) uute tantsude õppimine. Need põhjused on aga omavahel seotud, ning see asjaolu toetab ideed, et rahvatantsul ja heaolul on kompleksne seos. Näiteks positiivsete emotsioonide nimel rahvatantsuga tegelemine on statistiliselt oluliselt seotud sooviga suhelda kaaslaste ja rühmaliikmetega ( $r=0.374)$, säilitada head füüsilist vormi $(r=0.451)$, õppida uusi tantse $(r=0.549)$ ja publikule esineda $(r=0.388)($ kõigil olulisusnivoo $\mathrm{p}<0.01)$. Rahvuse/riigi esindamine on seotud publikule esinemisega $(r=0.332$; olulisusnivoo $\mathrm{p}<0.01)$, publikule esinemine omakorda uute tantsude õppimisega $(\mathrm{r}=$ 0.468; olulisusnivoo $\mathrm{p}<0.01$ ).

Sarnane põhjuste seos ilmneb ka rahvatantsuüritustel osalemises. Neljast peamisest rahvatantsuüritusel osalemise põhjusest eendus soov saada uusi sõpru, mis on statistiliselt oluliselt seotud sooviga suhelda juba olemasolevate sõpradega $(r=0.477)$, olles samaaegselt korrelatsioonis ka sooviga esineda publikule $(\mathrm{r}=0.367)$ (kõigil olulisusnivoo $\mathrm{p}<0.01)$.

Lisaks määratleti uurimuses eelnevalt neli peamist ürituste tüüpi, arvestades nende regionaalset tähtsust ja/või osavõtjate arvu: kohalikud väiksemad üritused (näiteks laatadel esinemine), väiksed riiklikud üritused (näiteks festivalid teistes linnades ja piirkondlikud peod), suured riiklikud üritused (näiteks laulu- ja tantsupidu ning ESTO päevad) ja rahvusvahelised üritused (näiteks rahvusvahelised festivalid). Selgus, et teatud tüüpi üritustel osalemisel mängivad olulist rolli erinevad põhjused; näiteks soov publikule esineda oli statistiliselt oluliselt seotud osalemisega suurtel riiklikel üritustel $(r=0.533)$ ja rahvusvahelistel üritustel $(\mathrm{r}=0.528)$ (kõigil olulisusnivoo $\mathrm{p}<0.01$ ). Soov saada uusi sõpru oli seotud rahvusvahelistel üritustel osalemisega $(r=0.425)$, kuid ka väikeste aastapäeva-üritustega ( $\mathrm{r}=0.417)$ (kõigil olulisusnivoo $\mathrm{p}<0.01$ ).

Kodu- ja väliseestlaste rahvatantsuharrastuse motiveerituse võrdlemiseks viidi läbi sõltumatute valimitega t-test. Tulemused näitasid, et kodueestlased rõhutavad mitmeid motiveerivaid faktoreid enam kui väliseestlased: näiteks soovi olla heas füüsilises vormis, esineda publikule ja kogeda positiivseid emotsioone (vt andmeid tabelis 1 ). 
Tabel 1. Rahvatantsu harrastamise põhjused kodu-ja väliseestlaste seas.

\begin{tabular}{|l|l|l|l|l|}
\hline $\begin{array}{l}\text { Rahvatantsu } \\
\text { harrastamise põhjus }\end{array}$ & $\begin{array}{l}\text { Kodu- } \\
\text { eestlased }\end{array}$ & $\begin{array}{l}\text { Välis- } \\
\text { eestlased }\end{array}$ & F & P \\
\hline Kaaslastega suhtlemine & 4.45 & 4.41 & 0.004 & 0.949 \\
\hline $\begin{array}{l}\text { Hea füüsilise vormi } \\
\text { säilitamine }\end{array}$ & 4.43 & 3.76 & 6.326 & 0.012 \\
\hline $\begin{array}{l}\text { Oma kultuuri/rahva } \\
\text { esindamine }\end{array}$ & 4.04 & 4.42 & 0.000 & 0.985 \\
\hline Publikule esinemine & 3.74 & 3.45 & 5.105 & 0.025 \\
\hline Positiivsed emotsioonid & 4.78 & 4.22 & 37.526 & 0.000 \\
\hline Uute tantsude õppimine & 4.50 & 4.14 & 2.981 & 0.085 \\
\hline
\end{tabular}

Tulemustest selgus, et kodueestlased olid motiveeritumad kui väliseestlased oma soovis publikule esineda (kodueestlased: $\mathrm{M}=4.27, \mathrm{SD}=0.858$; väliseestlased: $\mathrm{M}=3.89, \mathrm{SD}=1.086 ; \mathrm{t}(269)=3.144$; olulisusnivoo $\mathrm{p}<0.01$ ).

Kodu- ja väliseestlasi võrreldi eri tüüpi omapidudel osalemise tähtsustamise poolest (kasutades sõltumatute valimitega t-testi). Tulemused näitavad, et kodueestlased pidasid tähtsamaks osalemist kõikidel eri tüüpi ja tasemel rahvatantsuüritustel: väikestel riigisisestel üritustel, suurtel riigisisestel üritustel ja rahvusvahelistel üritustel (vt andmeid tabelis 2).

Tabel 2. Rahvatantsü̈ritustel osalemise tähtsus kodu- ja väliseestlaste silmis.

\begin{tabular}{|l|l|l|l|l|}
\hline $\begin{array}{l}\text { Rahvatantsuüritustel } \\
\text { osalemise tähtsus }\end{array}$ & $\begin{array}{l}\text { Kodu- } \\
\text { eestlased }\end{array}$ & $\begin{array}{l}\text { Välis- } \\
\text { eestlased }\end{array}$ & $\mathbf{F}$ & $\mathbf{P}$ \\
\hline $\begin{array}{l}\text { Väiksed kohalikud } \\
\text { üritused }\end{array}$ & 4.09 & 4.04 & 0.002 & 0.965 \\
\hline $\begin{array}{l}\text { Väiksed riigisisesed } \\
\text { üritused }\end{array}$ & 4.04 & 3.67 & 18.541 & 0.000 \\
\hline $\begin{array}{l}\text { Suured riigisisesed } \\
\text { üritused }\end{array}$ & 4.61 & 3.95 & 10.206 & 0.002 \\
\hline Rahvusvahelised üritused & 4.23 & 3.92 & 14.358 & 0.000 \\
\hline
\end{tabular}


Mees- ja naistantsijate rahvatantsupidudel osalemise motiveerituse erinevuse uurimiseks viidi läbi sõltumatute valimitega t-test, mille tulemused näitasid, et naistel oli soov õppida uusi tantse suurem kui meestel (mehed: $\mathrm{M}=4.13, \mathrm{SD}=$ 0.948; naised: $\mathrm{M}=4.49, \mathrm{SD}=0.756 ; \mathrm{t}(250)=-3.361$; olulisusnivoo $\mathrm{p}<0.05)$. Naised pidasid suurtel riiklikel üritustel osalemist tähtsamaks kui mehed (mehed: $\mathrm{M}=4.25, \mathrm{SD}=1.072$; naised: $\mathrm{M}=4.45, \mathrm{SD}=0.838 ; \mathrm{t}(274)=-1.662$; olulisusnivoo $\mathrm{p}<0.05)$.

Kui uuriti, kuidas mõjutab rahvatantsija vanus soovi rahvatantsu harrastada ja/või osaleda rahvatantsuüritustel, leidus ainult üks statistiliselt oluline (kuigi nõrk) korrelatsioon $(\mathrm{r}=0.121$, olulisusnivoo $\mathrm{p}<0.01)$. Rahvatantsu-üritustel osalemise põhjused ei olnud vanusega statistilise olulisusega seotud. Siiski oli vanus statistiliselt negatiivses (kuigi nõrgas) korrelatsioonis osalemisega erinevat tüüpi rahvakunstiüritustel, vanus oli negatiivses korrelatsioonis nii suurtel riiklikel üritustel osalemise tähtsusega $(\mathrm{r}=-0.206$; olulisusnivoo $\mathrm{p}<0.01)$ kui ka rahvusvahelistel üritustel osalemisega $(\mathrm{r}=-0.131$; olulisusnivoo $\mathrm{p}<0.05$ ).

Haridus ei seostunud ühegi rahvatantsu harrastamist või rahvatantsuüritustel osalemist puudutava motiveeriva faktoriga.

Et selgitada välja rahvatantsuharrastusega tegelemise põhjuste ennustatavust sõltumatute faktorite (sugu, vanus, päritolumaa, haridus ja rahvatantsuga tegelemise staaž) põhjal, viidi läbi regressioonanalüüs (Linear Regression, Method: Stepwise, analüüsis asendati puuduvad väärtused keskmistega). Kuna integreeritud regressioonianalüüs ei andnud statistiliselt olulisi tulemusi, konstrueeriti eraldi kuus regressioonianalüüsi mudelit. Need vastasid rahvatantsuga tegelemise kuuele põhjusele (kaaslastega suhtlemine, hea füüsilise vormi säilitamine, oma kultuuri/rahva esindamine, publikule esinemine, positiivsete emotsioonide saamine, uute tantsude õppimine). Regressioonianalüüsi tulemusena ei ilmnenud statistiliselt olulisi seoseid sõltumatute muutujate ja järgmiste motivatsioonitegurite vahel: kaaslastega suhtlemine, publikule esinemine. Seepärast jäeti lõplikust mudelist need välja. Regressioonianalüüsi lõplikud tulemused on esitatud tabelis 3. Antud analüüsietapi tulemustest võib järeldada, et kodu-eestlastele on olulisemad eeskätt rahvatantsu harrastuslikud aspektid, samas väliseestlastele on olulisem tunda ennast oma kultuuri/ rahva esindajana. Sooliste erinevuste puhul saab välja tuua asjaolu, et meeste silmis oli uute tantsude õppimine ja ennast oma kultuuri esindajana tundmine olulisemad kui naistel.

Regressioonianalüüs rahvatantsuürituste külastamise põhjuste kohta statistiliselt olulisi tulemusi ei andnud. 
Tabel 3. Rahvatantsuharrastusega tegelemise põhjused: regressioonanalüüsi tulemused.

\begin{tabular}{|l|l|l|l|l|}
\hline Rahvatantsuga & \multicolumn{3}{|l|}{ Regressioonikordaja, Beta } & \\
\cline { 2 - 5 } $\begin{array}{l}\text { tegelemine, } \\
\text { iseseisvad } \\
\text { faktorid }\end{array}$ & $\begin{array}{l}\text { Füüsilises } \\
\text { vormis olek }\end{array}$ & $\begin{array}{l}\text { Positiivsete } \\
\text { elamuste } \\
\text { saamine }\end{array}$ & $\begin{array}{l}\text { Uute tantsude } \\
\text { oppimine }\end{array}$ & $\begin{array}{l}\text { Oma rahva } \\
\text { esindajana } \\
\text { tundmine }\end{array}$ \\
\hline $\begin{array}{l}\text { Sugu (1. mees; } \\
\text { 2. naine) }\end{array}$ & 0.111 & 0.116 & $0.208^{* *}$ & $0.135^{*}$ \\
\hline $\begin{array}{l}\text { Haridus } \\
\text { (1. põhi-, } \\
\text { 2. kesk-, } \\
\text { 3. keskeri-, } \\
\text { 4. kõrgharidus) }\end{array}$ & -0.046 & 0.007 & 0.018 & -0.011 \\
\hline $\begin{array}{l}\text { Kui kaua oled } \\
\text { tegelenud } \\
\text { rahvatantsuga, } \\
\text { aastates? }\end{array}$ & $-0.224^{* *}$ & -0.144 & 0.063 & 0.014 \\
\hline $\begin{array}{l}\text { Päritolu } \\
\text { (1. Eesti, } \\
\text { 2. välismaa) }\end{array}$ & $-0.202^{* *}$ & $-0.259 * * *$ & $-0.177^{* * *}$ & $0.128^{*}$ \\
\hline $\begin{array}{l}\text { Vanus, } \\
\text { aastates }\end{array}$ & $0.243^{* *}$ & 0.094 & -0.086 & 0.113 \\
\hline & 0.078 & 0.098 & 0.058 & 0.05 \\
\hline R2 & 5.432 & 5.635 & 3.925 & 2.708 \\
\hline$F$ koefitsient & & & & \\
\hline
\end{tabular}

Märkused: (1) Rahvatantsuga tegelemise motivatsiooni suund on positiivne, (2) olulisusnivoo: $* p<0.05, * * p<0.01$, *** $p<0.001$. 


\section{Kvalitatiivne uurimus}

Kvalitatiivse uurimuse koguvalim koosnes kümnest rahvatantsijast keskmise vanusega 47,7 (SD = 16.49). Kümnest vastanust kaheksa olid väliseestlased (Kanadas, USA-s, Venemaal ja Austraalias), kaks kodueestlased. Viis respondenti olid mehed (väliseestlased), ja viis naised (kaks neist kodueestlased). Põhiliseks kriteeriumiks intervjuu respondentide valikul oli nende aktiivsus rahvatantsuga tegelemisel ning vähemalt kolmeaastane tantsu- ja esinemiskogemus, et saada andmeid tantsijate arvamuste ja tunnete kohta.

Kvalitatiivne uurimus viidi läbi, kasutades poolstruktureeritud intervjuud. Teemad puudutasid rahvatantsu kultuurilisi aspekte, rahvatantsuüritustel osalemise motivatsiooni ja rahvatantsu tähendust eestlaste silmis (nii kodu- kui väliseestlastel). Küsimuste järjekord ja sõnastus varieerusid sõltuvalt intervjuu kulgemisest.

Kõik intervjuud salvestati videole ning seejärel transkribeeriti sõna-sõnalt. Andmeid analüüsiti sisuanalüüsi meetodil, määratlemaks olulised kategooriad ja valdkonnad, iga ilmnenud kategooria kohta leiti märksõnad. Uurija subjektiivsuse vähendamiseks ja tulemuste usaldusväärsuse tõstmiseks kasutati triangulatsiooni (lisaks artikli autoritele osales grandi analüüsis tantsuterapeut, doktorant ja Tallinna Ülikooli teadur). Pärast kolme iseseisva analüüsi võrdlemist tehti ühised järeldused uurimistöö tarbeks.

Analüüsi esimese etapi käigus moodustati 19 esialgset kategooriat, mis kõik kirjeldasid eesti rahvatantsu erinevaid aspekte ja nende tähendust rahvatantsijatele. Analüüsi teises etapis moodustati viis eraldiseisvat üldkategooriat, mis kirjeldasid, kuidas rahvatantsijad (eriti need, kes olid sündinud või elasid välismaal) tunnetavad rahvatantsu kui kultuuritraditsiooni olemust ja tähendust (vt kvalitatiivse analüüsi täpseid tulemusi lisas 1). Kategooriate hulka arvati viis põhikategooriat: motivatsioon, identiteet, isiklikud suhted, seos teiste rahvakunstiharrastustega ja rahvatantsu eriline tähendus tantsijatele.

Järgnevalt on toodud viie põhikategooria kirjeldused:

- Motivatsioon: rahvatantsu harrastamine ja osalemine erinevatel rahvatantsuüritustel ehk regulaarse rahvatantsuharrastuse käivitajad. Põhimotivaatorite hulka kuulusid:

(a) kaaslastega koos olemine (kehtis nii nooremate kui ka vanemate rahvatantsijate puhul);

(b) rahvatantsu esitamine, nii oskused (soov näidata oma tantsuoskust ning omandatud kujundeid ja samme) kui ka publikule esinemise põnevus (kultuurilise eripära näitamise viis); 
(c) hea füüsilise vormi säilitamine;

(d) soov tantsida, nii rahvatantsu kui ka teisi tantsuliike; tants kui eneseväljenduse viis;

(e) vabatahtlik kaasamine, eriti noorte puhul (kui noor inimene saab rahvatantsuga lähemalt tuttavaks ning see toimub vabatahtlikult ja meeldival moel, hakkab ta suure tõenäosusega rahvatantsuga tegelema). Selles mõttes tundus rahvatantsul olevat teatud "elutsükkel" nooremad tantsijad katkestavad tantsimise umbes 18-20aastaselt, ent siis (tavaliselt seoses abiellumise ja laste saamisega) tullakse tantsu juurde tagasi alates 25.-28. eluaastast, sageli koos lastega, kellest saavad omakorda uue põlvkonna rahvatantsijad.

- Identiteet: nii kultuuriline (näiteks viis, kuidas rahvatantse tantsitakse, aitab ära tunda, et tegemist on just eesti rahvatantsuga) kui ka isiklik (näiteks kuidas inimene ennast rahvatantsuga tegelemise abil määratleb). Tants on oluline viis näitamaks, et ollakse osa eesti kultuurist, et säilitatakse eestlust ning sageli on väliseestlaste jaoks rahvatants üks väheseid viise näitamaks oma ajaloolisi juuri ja päritolu. Sageli tunnetatakse selle kultuurinähtuse olemust visuaalselt ainuomaste rahvariiete ja heliliselt teatud tüüpi viiside, rütmi ja tempo kaudu, aga ka eesti rahvatantsudes kasutatavate eriliste tantsuliigutuste, hoiakute ja sammude vahendusel. Identiteedikategoorias ilmnes ka üks teatud määral vastuoluline aspekt: nimelt käsitletakse rahvatantsu mõnikord kui midagi alamat, mis pärineb talurahvalt ja mida seetõttu ei saa võrrelda nn kõrgkultuuriga (näiteks ballett või ooper).

- Isiklikud suhted: rahvatantsu tunnetatakse sageli ka kui sotsialiseerumisvahendit, nii uute sõprade leidmiseks kui vanade sõprussuhete säilitamiseks (põimub motivatsiooni aspektidega). Siiski on eriti väliseestlastel rahvatants suhete loomise lähtepunktiks (näiteks pärast tantsutrenni sõpradega koos viibimine; sarnaste huvidega inimeste koos olemine ka väljaspool rahvatantsuharrastust). Rahvatantsul on haruldane omadus tuua selle tegevuse juurde terved perekonnad. Ei ole harvad need juhtumid, mil mitte-eestlastest abikaasad tulevad samuti rahvatantsutrenni ja osalevad üritustel. Isiklikud suhted peegelduvad ka pealtvaatajates, sh publiku äratundmine, silmside ja suhestumine pealtvaatajatega.

- Seos teiste tegevustega: üks rahvatantsu ainuomastest aspektidest (eriti väliseestlaste meelest) on asjaolu, et ta võimaldab eesti kultuurist osa saada ka nendel, kes ei valda eesti keelt. Kuna tants on kõigile arusaadav 
ja õpitav, ei pea tantsija valdama soravalt eesti keelt selleks, et tunda end eestlasena ja eesti kultuuri osana. Rahvatantsu vaadeldakse sageli rahvakultuuri erinevate väljendusvormide ühenduslülina - ta ühendab käsitöö (tantsijate rõivaste õmblemine) ja rahvamuusika (elava muusika või teatud ansamblite/pillimeeste salvestuste kasutamine esinemistel), samuti ühendab ta erinevaid kultuure (näiteks multikultuuriliste ürituste/festivalide ajal).

- Eriline tähendus: rahvatantsul on ajaloolised juured, mis on eriti oluline vanematele väliseestlastest rahvatantsijatele, kes lahkusid Eestist lastena mitukümmend aastat tagasi. Rahvatants on neile alati olnud mitte ainult osa nende isiklikust identiteedist, vaid ka osa nende pere pärandist ja kultuuriside kodumaaga, mida tuleb hoida ja pärandada põlvest põlve. Rahvatantsu nähakse millenagi, mis eristab eestlasi teistest kultuuridest. Eestlastele on ainuomane mitte üksnes tantsutraditsioon kui selline, vaid kogu seda ümbritsev aura - see mitmetahulisus, millega eestlased tantsu tunnetavad, kuidas seda õpivad ja traditsiooni edasi annavad.

Rahvatantsijad möönsid, et kuigi uute tantsude õppimiseks on olemas klassikalised kirjalikud ja visualiseeritud allikad, tekib üha suuremal hulgal uuendusi, mugandusi ja tõlgendusi selle kohta, mida rahvatants endast kujutab ja kuidas seda tantsida (näiteks videod YouTube'is, liigutuste ja sammude kohandamine vastavalt tantsijate võimekusele, repertuaari kohandamine vastavalt kättesaadavatele allikatele). Kodueestlased pööravad eelkõige tähelepanu rahvatantsu tehnilistele ja võistluslikele aspektidele, kuna neil on võimalus osa saada ka kõigist teistest rahvuskultuuri aspektidest (keel, uudised, muusika, kaaslased). Väliseestlased aga rõhutavad selle traditsiooni kultuurilist ja pärandatavat aspekti, sest sageli on see nende ainus side ajaloolise kodumaaga. Seda sidet saavad nad hoida ja arendada aktiivselt tegutsedes ning seeläbi tunda end endiselt kodumaal toimuvast osalisena. Eriti puudutab see väliseestlaste vanemat põlvkonda, kes püüab eesti rahvuskultuuri traditsioone nooremale põlvkonnale edasi andes säilitada eestlust ja rahvuslikku identiteeti.

\section{Kvantitatiivse ja kvalitatiivse uurimuse tulemuste kokkuvõte}

Lähtudes teooriast ja Eesti rahvatantsu traditsiooni muutunud olemusest oli käesoleva uuringu hüpotees, et rahvatantsu nähakse eelkõige kui seltskondlikku vaba aja veetmise vormi. Tõepoolest, tulemused näitavad, et vastanute enamuse silmis on sotsiaalne komponent äärmiselt tähtis. Ka Marju Lauristini 
ja Peeter Vihalemma laulupidusid käsitlevast uurimusest (2013) nähtub, et sotsiaalsus ja elamuslikkus on muutumas tantsu- ja laulupidude puhul üha suuremaks motivaatoriks eelkõige nooremate osalejate seas. Põhilised uurimisküsimused käsitlesid rahvatantsu harrastamise põhjuseid. Subjektiivse heaolu vaatevinklist on olulised neli peamist põhjust: positiivsed emotsioonid (sageli seotud ka teistega suhtlemisega), enda füüsilise vormi hoidmine, uute tantsude õppimine ja enda tundmine oma kultuuri/rahva esindajana. Füüsilise vormi hoidmine tundus eriti oluline just nooremate tantsijate meelest, kellele see on võrreldav trenniga. Tõsiasi, et vastastikust seotust hindasid kogu valimi ulatuses nii kodueestlased kui ka väliseestlased võib tõestada, et rahvatantsu ja heaolu tunde vaheline seos kehtib kõikjal, kuigi väliseestlased rõhutasid just rahvatantsuharrastuse kultuurilist aspekti rohkem kui kodueestlased. Mõnevõrra üllatuslikult ilmnes, et kodueestlased tähtsustavad rohkem erinevaid (eriti suuri riiklikke) rahvatantsuüritusi. Õigupoolest tõid kodueestlased sagedamini esile mitmeid rahvatantsu harrastamise põhjuseid, sealjuures ka võistluslikku tahku, et pääseda suurtele riiklikele üritustele (nagu laulu- ja tantsupidu). Üks võimalikke selgitusi võib siin olla asjaolu, et kodueestlased teavad sellistest üritustest rohkem kui väliseestlased. Eestis on rahvatantsuhuvilistel märksa lihtsam kokku tulla, ühineda juba tegutseva tantsurühma või -kooliga ning seejärel osaleda juba rahvatantsuüritustel. Teine võimalik selgitus on kodueestlaste ajaloolised ja poliitilised traditsioonid. Enne taasiseseisvumist 1991. aastal oli Eesti ligi 50 aastat olnud osa Nõukogude kommunistlikust süsteemist, mis rõhutas kollektivismi ja oli vastu igasugusele individualismile. Pärast 1991. aastat hakkasid väärtused ja vaated muutuma, turumajanduse ajastul sai heaolu ja edukuse nurgakiviks individualism. Võib-olla ilmnevad sellised drastilised muutused eriti teravalt just noortes demokraatiates, see selgitaks erinevust kodu- ja väliseestlaste vahel. Väliseestlastel esineb rahvatantsurühmade moodustamisel ka rohkem takistusi (geograafilisi, ealisi, finantsilisi), lisaks rahvatantsu pideva mõju nappus ja märksa laiem alternatiivide valik. Ootamatu oli korrelatsiooni puudumine rahvatantsu harrastamise motiveerituse ja haridustaseme vahel - vähemalt antud uurimuse valguses ei saanud hariduse põhjal ennustada, miks harrastati rahvatantsu või käidi rahvatantsuüritustel. Nt Marju Lauristini ja Peeter Vihalemma uurimusest (2013) ilmnes selge seos haridustaseme ja laulupeol osalemise vahel: kõrgharidusega osalejate meelest olid primaarsed rahvustunne ja koos saadud elamus, keskharidusega osalejatele oli esmatähtis samuti rahvustunne ja koostegemine, põhiharidusega osalejatele aga osalemine ja (omavahel) jagatud kogemus. Meie uurimuse tulemused võivad osaliselt tuleneda vastanute suhteliselt kõrgest keskmisest vanusest, aga ka antud valimi üldspetsiifikast (näiteks meeste ja naiste erinev osakaal kodu- ja väliseestlaste hulgas). Konkreetne valim võis 
tingida ka erinevuse eri tüüpi rahvatantsuüritustel osalemise motiveerituses: kuigi keskmiselt hindasid kodueestlased kõrgelt pigem osalust igal tasemel (väikesed ja suured riiklikud üritused ja rahvusvahelised üritused), rõhutasid nii kodu- kui ka väliseestlased kõige enam osalust suurtel riiklikel üritustel. Üks võimalikest põhjustest võis olla see, et ürituse tüübi määratlust - "väike kohalik/riiklik üritus" - võisid kodueestlased ja väliseestlased tõlgendada erinevalt, mis tuleneb geograafilise skaala erinevusest, võimalusest osaleda ühel või teisel üritusel ning tähendusest, mida osalejad antud üritusele andsid.

Kindlasti mõjutavad tulemuste tõlgendamist ja järelduste tegemist meie uurimuse valimi suurus ja spetsiifika. Näiteks naisvastanute oluliselt suurem osakaal võib põhjuste ja seoste puhul kallutada tulemusi, samas ilmnesid ka Lauristini ja Vihalemma uurimuses (2013) teatud erinevused naiste ja meeste motivatsioonis laulupidudest osa võtta. Uurimuse kvalitatiivse osa väikene valim ei esinda kindlasti absoluutset tõde ega täit pilti, pigem on uurimuse autorid püüdnud esitada rahvatraditsioonide hoidmisega seotud arvamuste, hinnangute ja hoiakute mitmekesisust. Intervjuu tulemusi võib käsitleda kui illustreerivat materjali, rahvatantsuharrastajate võimalikku vaatenurka ja tajutavat tähendust nende endi silmis.

Rahvatantsu harrastamise tähenduse ja olemuse juures rõhutasid väliseestlased kultuuripärandit, rahvatraditsioonide järjepidevust ja nende edasiandmist väliseestlaste uutele põlvkondadele. Kodueestlased peavad aga rahvatantsu eneseväljendusvahendiks ning võimaluseks näidata oma oskusi ja esineda suure publiku ees. See on osa suuremast ja keerulisest loomulikust kultuuri säilitamisest, kus rahvatants esindab rahvakultuuripärandi tehnilist (aga ka universaalset) aspekti.

\section{Järeldused}

Jätkuva globaliseerumise ajajärgul on kohalike rahvatantsu harrastamise ja traditsioonide säilitamine ning nende kohandamine uute põlvkondade vajadustega oluline ka inimeste heaolu parandamise seisukohast. Viimastel aastatel on rahvatantsu vaba aja veetmise, sportlikud ja sotsialiseerumise aspektid omandanud samaväärse tähtsuse kultuurilise aspektiga. Väidetakse, et igasugune huvipõhine tegevus suurendab inimese rahulolu eluga ja seega ka tema subjektiivset heaolu. Rahvakunstiga tegelemist (ja eriti rahvatantsu harrastamist) motiveerivad faktorid on komplekssed, mitmetahulised ning seovad kõiki sotsialiseerumise, õppimise ja saavutamise aspekte, samuti teisi subjektiivse heaoluga seotud faktoreid. Nii nagu mitmed varasemad uurimused (nt Minkov 2009; Brown et al. 2015), on ka käesolev uurimus näidanud harrastuste ja SH 
tugevat ja püsivat seost. Rahvatants tugevdab inimese sotsiaalseid suhteid ja teistega suhtlemise oskust ning aitab säilitada kultuurilise, rahvusliku ja kogukondliku kuuluvuse tunnet, mis omakorda oluliselt suurendab inimese rahulolu eluga. Intervjuudes välja tulnud võistluslikkuse aspekt peegeldab rahvatantsu kui kultuurinähtuse muutuvat olemust. See on jätkuvalt sajanditepikkuse kultuuripärandi säilitamine aktiivse õppimise, tegevuse ja esinemiste vahendusel. Seda kultuuritraditsiooni saavad kujundada, vormida, täiustada ja seega ka muuta nii tantsijad kui ka pealtvaatajad. Paeluv on mõelda, et me säilitame vanu traditsioone (rahvatantse) ja samal ajal kinnistame meie praegusi väärtusi ja uskumusi selle pärandi taasesitusse. Sarnaselt rahvakunsti paljude teiste tahkudega saab ka rahvatants edasi elada ainult siis, kui selle kunstivormiga aktiivselt tegeldakse. Kuid rahvatantsu teeb eriliseks tema pideva taasesitamise nõue, mida saadavad tehnilised ja visuaalsed täiendused.

Väiksed kultuurid ja rahvad (arvestuslikult on eestlasi maailmas ligi miljon) peavad märksa enam kohanduma kõikjale levivate globaalsete kultuuritendentside mõjuga. Teave selle kohta, kuidas sajandeid vanu traditsioone kaasaegsesse ellu integreerida, võiks olla kasulik paljudele teistelegi väikerahvastele, kes tahavad oma eripära ja traditsioone säilitada. See on oluline mitte ainult ajaloolisest või etnoloogilisest perspektiivist lähtudes, vaid aitab ka suurendada nende rahvaste heaolu, psühholoogilist tervist ja üldist eluga rahulolu.

\section{Tänuavaldused}

Käesolev uuring viidi läbi ETF uurimisprojekti "Rahvatantsuharrastuse ja rahvatantsijate suurürituste roll omakultuuri hoidmisel" (grant nr 9132) raames, mida juhib Tallinna Ülikooli rakendusloome vanemteadur Iivi Zajedova. Artikli autorid tänavad kõiki grandis osalenuid ning eriti väljaspool Eestit elavaid rahvatantsujuhte ja rahvatantsijaid lahke abi eest andmete kogumisel.

\section{Kommentaar}

1 Käesolev uurimistöö on osa Tallinna Ülikooli uurimisprojektist "Rahvatantsuharrastuse ja rahvatantsijate suurürituste roll omakultuuri hoidmisel", mida rahastab ETF, grant number 9132. 


\section{Kirjandus}

Aassalu, Heino 1999. Murrangud Eesti rahvatantsus ja harrastusrahvatantsus XX sajandil. Tallinn: Rahvakultuuri Arendus- ja Koolituskeskus.

Adari, Aadu \& Mikkin, Heino (toim) 1939. 2. Eesti Mängude juht. Tallinnas 16., 17. ja 18. juunil 1939. Tallinn: Eesti Spordi Keskliit.

Arraste, Angela \& Zajedova, Iivi \& Rüütel, Eha 2011. Rahvatantsuharrastusega seotud kultuuri- ja suurpeod väljaspool Eestit. Mäetagused 49, lk 49-64 (doi: 10.7592/ MT2011.49.valispeod).

Balatsky, Galina \& Diener, Ed 1993. Subjective well-being among Russian students. Social Indicators Research 28, lk 225-243 (doi: 10.1007/BF01079019).

Bostic, Terence J. \& Ptacek, John T. 2001. Personality factors and the short-term variability in subjective well-being. Journal of Happiness Studies 2, lk 355-373 (doi: 10.1023/A:1013929030931).

Brajša-Zganec, Andreja \& Merkas, Marina \& Sverko, Iva 2011. Quality of life and leisure activities: How do leisure activities contribute to subjective well-being? Social Indicators Research 102 (1), lk 81-91 (doi: 10.1007/s11205-010-9724-2).

Brown, Jennifer L. \& MacDonald, Ronald \& Mitchell, Richard 2015. Are people who participate in cultural activities more satisfied with life? Social Indicator Research 122, lk 135-146 (doi: 10.1007/s11205-014-0678-7).

Carter, Shani D. 2004. Reexamining the temporal aspects of affect: Relationships between repeatedly measured affective state, subjective well-being, and affective disposition. Personality and Individual Differences 36, lk 381-391 (http://dx.doi.org/10.1016/S01918869(03)00103-X).

Diener, Ed 1984. Subjective well-being. Psychological Bulletin 95, lk 542-575 (doi: 10.1037/0033-2909.95.3.542).

Diener, Ed \& Diener, Marissa 1995. Cross cultural correlates of life satisfaction and selfesteem. Journal of Personality and Social Psychology 68, lk 653-663 (doi: 10.1037/00223514.68.4.653).

Diener, Ed, \& Seligman, Martin E. P. 2004. Beyond money: Toward an economy of wellbeing. Psychological Science in the Public Interest 5, lk 1-31 (http://internal.psychology. illinois.edu/ ediener/Documents/Diener-Seligman_2004.pdf - 6. november 2015).

Diener, Ed \& Suh, Eunkook M. \& Lucas, Richard E. \& Smith, Heidi L. 1999. Subjective well-being: Three decades of progress. Psychological Bulletin 125(2), lk 276-302 (doi: 10.1037/0033-2909.125.2.276).

Keyes, Corey L. M. 1998. Social well-being. Social Psychology Quarterly 61 (2), lk 121-140 (doi: 10.2307/2787065).

Keyes, Corey L. M. \& Magyar-Moe, Jeana L. 2003. The measurement and utility of adult subjective well-being. Lopez, Shane J. \& Snyder, C. R. (toim). Positive psychological assessment. A handbook of models and measures. Washington, DC: American Psychological Association, lk 411-425 (http://dx.doi.org/10.1037/10612-026). 
Korb, Anu 2012. Siberi eestlaste kohanemisest ja sulandumisest pärimusainese põhjal. Mäetagused 50, lk 47-70 (doi: 10/7592/MT2012.50.korb).

Korb, Anu (toim) 2014. Eestlased Venemaal: elud ja lood. Tartu: Eesti Kirjandusmuuseumi Teaduskirjastus.

Korb, Anu 2015. Oma toit: muutustest Siberi eestlaste toidukultuuris. Mäetagused 59, lk 125-150 (doi: 10/7592/MT2015.59.korb).

Kumer-Haukanõmm, Kaja \& Rosenberg, Tiit \& Tammaru, Tiit (toim) 2006. Suur põgenemine 1944. Eestlaste lahkumine läände ning selle mõjud. 22. oktoobril 2004 Tartus toimunud rahvusvahelise teaduskonverentsi artiklite kogumik. Tartu: Tartu Ülikooli Kirjastus.

Lauristin, Marju \& Vihalemm, Peeter 2013. Minu laulu- ja tantsupidu: sotsioloogilise uuringu aruanne. Tartu: Eesti Laulu- ja Tantsupeo SA (http://2014.laulupidu.ee/wpcontent/uploads/2014/01/Laulupeo-uuringu-aruanne-oktoober-2013.pdf - 5. november 2015).

Menec, Verena H. \& Chipperfield, Judith G. 1997. Remaining active in later life: The role of locus of control in seniors' leisure activity participation, health, and life satisfaction. Journal of Aging \& Health 9, lk 105-125 (doi: 10.1177/089826439700900106).

Minkov, Michael 2009. Predictors of Differences in Subjective Well-Being Across 97 Nations. Cross-Cultural Research 43, lk 152-179 (doi: 10.1177/1069397109332239).

Newman, David B. \& Tay, Louis \& Diener, Ed 2014. Leisure and Subjective WellBeing: A Model of Psychological Mechanisms as Mediating Factors. Journal of Happiness Studies 15, lk 555-578 (doi: 10.1007/s10902-013-9435-x).

Reynolds, Frances \& Lim, Kee Hean 2007. Contribution of visual art-making to the subjective well-being of women living with cancer: A qualitative study. The Arts in Psychotherapy 34, lk 1-10 (doi: 10.1016/j.aip.2006.09.005).

Rüütel, Ingrid \& Kapper, Sille 2015. Kihnu tantsud. Tartu: Eesti Kirjandusmuuseumi Teaduskirjastus.

Rüütel, Eha \& Zajedova, Iivi \& Arraste, Angela 2013. Motivational underpinnings of Estonian folk dance practices among the Estonian diaspora over time. Folklore: Electronic Journal of Folklore 54, lk 97-118 (doi: 10.7592/FEJF2013.54.ryytel_zajedova_arraste).

Ryff, Carol D. 1989. Happiness is everything or is it? Explorations on the meaning of psychological well-being. Journal of Personality and Social Psychology 57, lk 1069-1081 (http://mina.education.ucsb.edu/janeconoley/ed197/documents/ryffHappinessiseverythingorisit. pdf-30. oktoober 2015).

Zajedova, Iivi 2008a. Cultural Expression - Estonia. Bateman, Graham (toim). World and Its Peoples. Poland and the Baltic States. Oxford: Oxford University Press, lk 1063-1065.

Zajedova, Iivi 2008b. Harrastustegevuse rahvusvaheline seminar. Mäetagused 40, lk 111-112 (http://www.folklore.ee/tagused/nr40/uudis.pdf - 6. november 2015).

Zajedova, Iivi 2013. Eesti päevad Austraalias. Mäetagused 53, lk 136-137 (http://www. folklore.ee/tagused/nr53/u04.pdf - 6. november 2015). 
Zajedova, Iivi 2015. Eestlaste kultuuripidu “Üle ilma”. Mäetagused 59, lk 166-168 (http:// www.folklore.ee/tagused/nr59/u04.pdf - 6. november 2015).

Zajedova, Iivi \& Rüütel, Eha 2014. Folk Dance Practice and Transmission of the Folk Dance tradition by Expatriate Estonians in Sweden and Germany. Český Lid. Etnological Journal (ustav AVCR, v. v. i.) 101, lk 57-76.

Tamannaeifar, Mohammad Reza \& Motaghedifard, Mahshad 2014. Subjective wellbeing and its subscales among students: The study of role of creativity and self-efficacy. Thinking Skills and Creativity 12, lk 37-42 (doi: 10.1016/j.tsc.2013.12.003).

Uchida, Yukiko \& Norasakkunkit, Vinai \& Kitayama, Shinobu 2004. Cultural constructions of happiness: Theory and empirical evidence. Journal of Happiness Studies 5, lk 223-239 (doi: 10.1007/s10902-004-8785-9).

Yarnal, Careen Mackay \& Chick, Garry \& Kerstetter, Deborah L. 2008. 'I did not have time to play growing up... so this is my play time. It's the best thing I have ever done for myself: What is play to older women? Leisure Sciences 30, lk 235-252 (doi: 10.1080/01490400802017456).

\section{Lisa 1.}

\section{Kvalitatiivse analüüsi tulemusena esile kerkinud kategooriad}

\begin{tabular}{|l|l|}
\hline Esialgsed ühised teemad & \multirow{2}{*}{ Kategooriad } \\
\hline Kaaslastega koos olemine & \\
\cline { 1 - 1 } Esitus (oskused) & \multirow{2}{*}{ Motivatsioon } \\
\hline Füüsiliselt heas vormis olemine & \\
\hline Armastus tantsu vastu & \\
\hline Unikaalsuse väljendus & \\
\hline Vabatahtlikkuse aspekt & \\
\hline Igaühe jaoks eriline tähendus & \\
\hline Kaasatuse põlvkondlik tsüklilisus & \\
\hline Kultuuriline identiteet & \\
\hline Eesti juured, “eestluse” tunnetamine & \\
\hline Rahvarõivad & \\
\hline Rahvamuusika & \\
\hline Rahvatantsu tajumine “teise kategooria” kultuurina & \\
\hline
\end{tabular}




\begin{tabular}{|c|c|}
\hline Sõprade leidmine & \multirow{6}{*}{ Isiklikud suhted } \\
\hline Sotsialiseerumine & \\
\hline Tegevused pärast trenni (koos välja minemine) & \\
\hline Kogu perekonna kaasamine & \\
\hline Sõprade/pere/paariliste leidmine & \\
\hline Suhestumine pealtvaatajatega & \\
\hline Seos teiste tegevustega & \multirow{4}{*}{ Seos teiste tegevustega } \\
\hline Teiste rahvakultuuritraditsioonide ühendamine & \\
\hline Eestlaseks jäämine ilma keelt oskamata/rääkimata & \\
\hline Enda tundmine eestlasena tegevuste abil & \\
\hline Füüsiline tähendus & \multirow{4}{*}{ Eriline tähendus } \\
\hline Suhe, seos kodumaaga & \\
\hline Unikaalsus, kordumatus, erinevus teistest & \\
\hline Eesti kultuuriruumi kuulumise mitmetahuline tajumine & \\
\hline
\end{tabular}

\title{
Summary
}

\section{Folk dance activities and participation in grand events: Reasons and correlations with subjective wellbeing}

\author{
Stanislav Nemeržitski, Iivi Zajedova
}

Keywords: folk dance, leisure activities, subjective wellbeing

Big festivals and folk culture events have been a centuries-old tradition in Estonia. Today, alongside the preservation of national traditions and being cultural events, these events have also become popular leisure activities. Leisure activities are known for their positive effect on humans' subjective wellbeing through emotional, social and psychological effects. This article focuses on adults' motivation, both in Estonia and abroad, to engage in folk dance activities and their possible impact on subjective wellbeing. The study was carried out among Estonians living in Estonia and abroad, and it was designed as a mixed methods research. The results indicate that social factors play an important role in motivating adults to engage in folk dance, but also educational aspects are involved, which contribute to the general wellbeing of a folk dancer. 